\section{OPEN ACCESS}

Edited by:

Susana Agusti,

King Abdullah University of Science and Technology, Saudi Arabia

Reviewed by:

Andrew Decker Steen,

The University of Tennessee,

Knoxville, United States

Federico Baltar

University of Vienna, Austria

*Correspondence:

Qi-Long Qin

qinqilong@sdu.edu.cn

Specialty section:

This article was submitted to

Aquatic Microbiology,

a section of the journal

Frontiers in Microbiology

Received: 30 May 2019

Accepted: 30 August 2019

Published: 13 September 2019

Citation:

$L i Y$, Sun $L-L$, Sun $Y-Y$, Cha $Q-Q$, Li C-Y, Zhao D-L, Song $X-Y$, Wang $M$, McMinn A, Chen $X-L$, Zhang $Y-Z$ and

Qin Q-L (2019) Extracellular Enzyme Activity and Its Implications for Organic Matter Cycling in Northern

Chinese Marginal Seas.

Front. Microbiol. 10:2137.

doi: 10.3389/fmicb.2019.02137

\title{
Extracellular Enzyme Activity and Its Implications for Organic Matter Cycling in Northern Chinese Marginal Seas
}

\author{
Yi Li', Lin-Lin Sun', Yuan-Yuan Sun', Qian-Qian Cha', Chun-Yang Li' ${ }^{2}$, Dian-Li Zhao', \\ Xiao-Yan Song ${ }^{1}$, Min Wang ${ }^{2}$, Andrew McMinn ${ }^{2,4}$, Xiu-Lan Chen ${ }^{1}$, Yu-Zhong Zhang ${ }^{1,2,3}$ \\ and Qi-Long Qin ${ }^{1 *}$
}

' State Key Laboratory of Microbial Technology, Marine Biotechnology Research Center, Shandong University, Qingdao, China, ${ }^{2}$ College of Marine Life Sciences, Ocean University of China, Qingdao, China, ${ }^{3}$ Laboratory for Marine Biology and Biotechnology, Qingdao National Laboratory for Marine Science and Technology, Qingdao, China, ${ }^{4}$ Institute for Marine and Antarctic Studies, University of Tasmania, Hobart, TAS, Australia

Extracellular enzymes, initiating the degradation of organic macromolecules, are important functional components of marine ecosystems. Measuring in situ seawater extracellular enzyme activity (EEA) can provide fundamental information for understanding the biogeochemical cycling of organic matter in the ocean. Here we investigate the patterns of EEA and the major factors affecting the seawater EEA of Chinese marginal seas. The geographic distribution of EEA along a latitudinal transect was examined and found to be associated with dissolved organic carbon. Compared with offshore waters, inshore waters had higher enzyme activity. All the tested substrates were hydrolyzed at different rates and phosphatase, $\beta$-glucosidase and protease contributed greatly to summed hydrolysis rates. For any particular enzyme activity, the contribution of dissolved to total EEA was strongly heterogenous between stations. Comparisons of hydrolysis rates of the polymers and their corresponding oligomers suggest that molecule size does not necessarily limit the turnover of marine organic matter. In addition, several typical enzyme-producing clades, such as Bacteroidetes, Planctomycetes, Chloroflexi, Roseobacter, Alteromonas, and Pseudoalteromonas, were detected in the in situ environments. These enzyme-producing clades may be responsible for the production of different enzymes. Overall, each enzyme was found to flexibly respond to environmental conditions and were linked to microbial community composition. It is likely that this activity will profoundly affect organic matter cycling in the Chinese marginal seas.

\section{Keywords: extracellular enzyme, distribution pattern, enzyme-producing clades, DOC utilization, environmental factors, Chinese marginal seas}

\section{INTRODUCTION}

Microorganisms play a key role in organic matter remineralization in the ocean. An estimated $50 \%$ of primary production in the surface water is transformed, repackaged, and respired via the microbial loop (Azam et al., 1983; Arnosti et al., 2005; Azam and Malfatti, 2007). Most of the organic matter in the ocean is in the form of chemically complex macromolecules and these polymers 
are too large to be transported across the cytoplasmic membrane (Arnosti, 2004). They must initially be hydrolyzed into small molecules $(<600 \mathrm{Da})$ by extracellular enzymes before uptake by the microbial cell (Weiss et al., 1991). Extracellular enzymes are, therefore, key factors affecting the organic matter cycling in marine ecosystems (Arnosti, 2010; Orsi et al., 2018).

Marine microbial extracellular enzymes are either cellassociated or dissolved in the water column (Chróst, 1991; Baltar et al., 2010). Cell-associated enzymes are bound to the cell surface, or localized in the periplasmic space (Reintjes et al., 2019). These enzymes present a cost-efficient strategy for freeliving microbes. Due to the dilute nature of dissolved organic matter (DOM), they can help the cell to preferentially access DOM (Chróst, 1991). However, the substrate must penetrate the cell wall or be physically located near the cell (Allison et al., 2012). Some polysaccharides substrates could be directly taken up into the periplasm of 'selfish' organism without production of extracellular hydrolysis products (Reintjes et al., 2017, 2019; Hehemann et al., 2019). Dissolved enzymes, which belong to a kind of "living dead" realm (Baltar, 2018), may originate from active secretion by cell (Alderkamp et al., 2007), bacterial starvation (Albertson et al., 1990) and changes in cell permeability (Chróst, 1991). Besides, they can also be produced in the process of grazing on bacterial communities and release during viral lysis (Chróst, 1991; Bochdansky et al., 1995; Baltar, 2018). As they spread, these enzymes can hydrolyze distant substrates, but hydrolysis products may not be harvested by the parent cell. Due to long lifetime, especially in the deep waters, dissolved enzymes perform their important function away from the cell (Baltar et al., 2013). In many cases, dissolved EEA could make up a substantial proportion (up to 100\%) of the total marine EEA (Baltar et al., 2010, 2016; Arnosti, 2010), which could indicate a disconnection between marine microbes and enzymatic activities (D'ambrosio et al., 2014). For particleassociated microbes, a 'secreting dissolved enzyme' strategy may be profitable due to the high nutrient concentrations on particles or relaxing requirement for cellular contact with particle organic matter (Vetter and Deming, 1999; Grossart et al., 2007; Baltar et al., 2019). These microbes exhibit a loose hydrolysis-uptake coupling with the substrate (Baltar et al., 2010). Sometimes, the 'secreting dissolved enzyme' strategy may also be favorable for free-living microbes through cooperative efforts, although it presumably is costly (Pai et al., 2012; Celiker and Gore, 2013).

Because most marine microbes cannot be cultured and because of the uncertainty of genomic and in situ gene investigations, there is no adequate information that either represents extracellular enzyme activity (EEA) in marine ecosystems or element recycling on global scales (Arnosti, 2010). Thus, in situ measuring of EEA that can provide a fundamental understanding of the biogeochemical cycling of organic matter is important and has been recognized in field studies (Arnosti, 2010). However, most measurements of enzyme activity use low molecular weight substrate proxies to extrapolate biopolymer enzyme activity. These proxies lack the three-dimensional structure of biopolymers in solution and cannot reflect the real degradation of polymers (Arnosti, 2010). Hence, little is known about the hydrolysis rates of real polymers. A further limitation is that the substrate proxies do not represent the activity of endoacting enzymes that cleave to the inside of a polymer chain. Although several fluoresceinamine labeled polysaccharides have been used to measure polysaccharide degrading enzymes in the marine ecosystem (Reintjes et al., 2017, 2019), the activity of extracellular enzymes on proteinaceous polymers, that constitute a large proportion of organic matters of primary production, has not been measured. Furthermore, almost nothing is known about the differences in hydrolysis rates between polymers and their corresponding oligomers.

The southern Yellow Sea is a semi-enclosed marginal sea bordered by the Chinese mainland and the Korean Peninsula. In the south, it is open to the East China Sea, which is one of the largest marginal seas in the world and has an extensive continental shelf area (Lee et al., 2014; Wei et al., 2016).

Freshwater discharge from the Yangtze River mixes with the surrounding high salinity waters in the East China Sea (Su and Weng, 1994). Due to high riverine nutrient load as well as pollution, phytoplankton blooms often occur in the southern Yellow Sea and East China Sea region (Fan and Song, 2014). Little is known about the distribution of EEA and the key factors affecting enzyme activity in this region. One limitation of measuring in situ EEA is that the natural concentration of extracellular enzymes is often too low to be measured directly. In this study, a tangential flow filtration system was used to concentrate the extracellular enzymes so that the EEA on biopolymer substrates (carboxymethyl cellulose (CMC), chitin, alginic acid and casein) could be measured directly. Based on the same chemical structure, we compared the hydrolysis rates of the polymers and their corresponding oligomers to study whether substrate size can affect the hydrolysis rate. The pattern of dissolved and total EEA and corresponding determinant environmental factors were also analyzed.

\section{MATERIALS AND METHODS}

\section{Sampling and Physicochemical Analysis}

A total of 11 samples were sampled from two regions, i.e., the inshore region with a bottom depth $<55 \mathrm{~m}$ (including stations $\mathrm{C} 2, \mathrm{D} 4$, and $\mathrm{F} 1$ ) and the offshore region with a bottom depth $>55 \mathrm{~m}$ (including stations B5, C4, F6, P6, S4, E4, W4 and T4). Surface water was taken at approximately $2 \mathrm{~m}$ water depth using a submersible pump during a cruise of R/V Dong Fang Hong-2, from 26 June to 19 July, 2018 (Figure 1). After prefiltration through 20- $\mu \mathrm{m}$-pore-size filters (Millipore Co., United States) to eliminate large particles and organisms, 10-1 seawater samples were filtered on board through $0.22-\mu \mathrm{m}$ polycarbonate membranes (Millipore Co., United States). Filters for DNA extraction were immediately placed in liquid nitrogen and frozen at $-80^{\circ} \mathrm{C}$ (Thermo Scientific, United States). Additional pre-filtered 10-1 seawater samples were concentrated to $50 \mathrm{ml}$ using a tangential flow filtration system with 5000-Dalton hollow modified polyethersulfone membranes (Spectrum Laboratories, Inc., United States). The concentration process was completed within $2 \mathrm{~h}$ and the samples were used for EEA measurement. For this, $25 \mathrm{ml}$ of the concentrated 


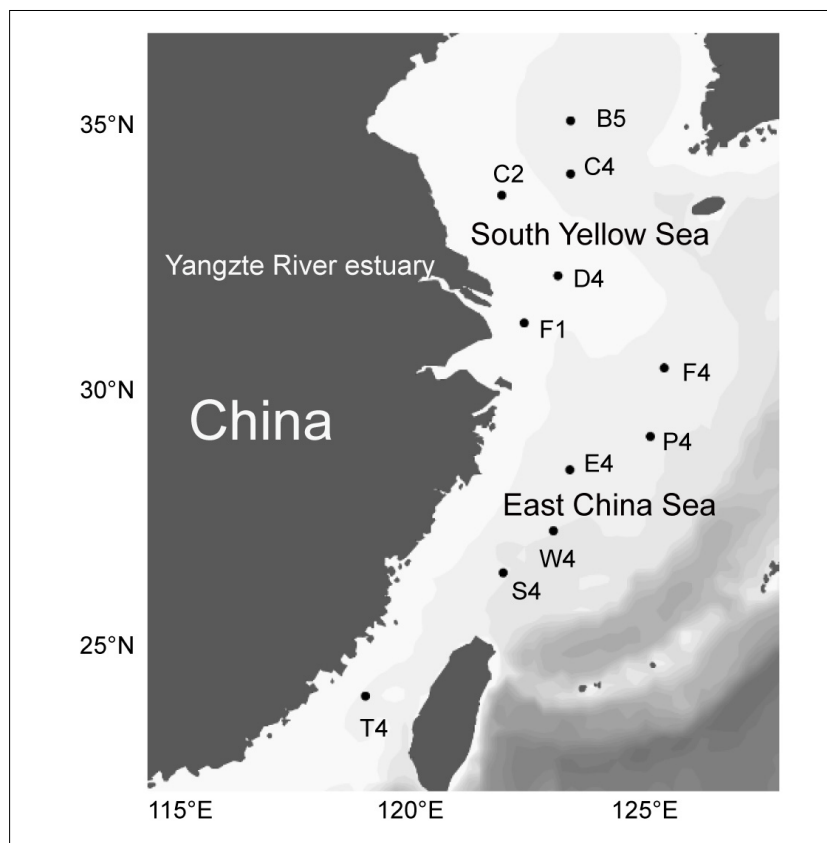

FIGURE 1 | Sampling stations in the southern Yellow Sea and East China Sea.

seawater samples were gently and manually filtered through a $0.22-\mu \mathrm{m}$-pore-size polypropylene Millex-GP Syringe filter (Millipore Co., United States) to separate cell-associated enzymes from dissolved enzymes following a previously reported protocol (Kim et al., 2007). The water samples for enzyme activity measurement were stored at $4^{\circ} \mathrm{C}$ until the experiments began within $1 \mathrm{~h}$ in the onboard lab. Water temperature, salinity, depth, $\mathrm{pH}$ and dissolved oxygen were recorded by the onboard conductivity-temperature-depth sensor (Sealogger, Sea-Bird Co., United States). Water samples for DOC and chlorophyll a (chl-a) were immediately frozen at $-20^{\circ} \mathrm{C}$. Water samples for nutrient contents $\left(\mathrm{NH}_{4}{ }^{+}, \mathrm{NO}_{2}{ }^{-}, \mathrm{NO}_{3}{ }^{-}\right.$, and $\left.\mathrm{PO}_{4}{ }^{3-}\right)$ were filtered through $0.45-\mu \mathrm{m}$ cellulose acetate membranes and then measured by spectrophotometric and colorimetric analyses. Chla concentration was extracted with $90 \%$ acetone and then determined by using a spectrophotofluorimetry method (HolmHansen et al., 1965). DOC content was measured by a TOC analyzer (Thermo Flash 2000 Elemental Analyzer, United States).

\section{Measurements of Enzyme Activity}

The hydrolysis rates of nine different substrates (five low molecular weight4-nitrophenyl analogs and four high molecular weight (HMW) polymers) were measured. Enzyme assays were conducted at $25^{\circ} \mathrm{C}$ (average ambient temperature). To study the effect of warming of seawater on enzymatic activity, enzyme assays were also conducted at $35^{\circ} \mathrm{C}$ (high temperature), which represents a "heat wave" type of scenario. The measured EEA in the unfiltered seawater was defined as the total enzyme activity and the measured EEA of the seawater passing through the $0.22-\mu \mathrm{m}$ filter was defined as the dissolved enzyme activity. In this study, they were measured with high substrate concentrations (well above in situ concentrations) to ensure EEA be measured as much as possible. Thus, the measured enzyme activities are potential values, which are not indicative of the actual rates of enzymatically catalyzed reactions under natural conditions (Wallenstein and Weintraub, 2008).

The hydrolysis rates of 4-nitrophenyl laurate (C12), 4-nitrophenyl phosphate disodium salt hexahydrate (PDSH), 4-nitrophenyl- $\alpha$-D-glucopyranoside (AG), 4-nitrophenyl- $\beta$-Dglucopyranoside (BG) and 4-nitrophenyl-N-acetyl- $\beta$-D-glucopyranoside (NAG) were measured to estimate the activities of lipase, phosphatase (Pase), $\alpha-, \beta$-glucosidase (AGase, BGase) and $\mathrm{N}$-acetyl-glucosaminidase (NAGase), respectively. Three polysaccharides (CMC, chitin and alginic acid) were used as substrates to measure the activities of cellulase, chitinase, and alginate lyase, respectively. Casein was used as the substrate to measure protease activity. All chemicals were obtained from Sigma-Aldrich (United States).

After the test, all reaction systems and incubation time were determined to ensure the reasonability of data. For 4-nitrophenyl analogs, the reaction system contained $30 \mu \mathrm{l} 50 \mathrm{mM}$ substrate and $470 \mu \mathrm{l}$ of the concentrated seawater sample. After incubation for $5 \mathrm{~h}$, the reaction was terminated by Tris- $\mathrm{NaOH}(\mathrm{pH} 12.0)$ and the absorbance of the reaction mixture was measured at $405 \mathrm{~nm}$. For the hydrolysis of the CMC and chitin, $30 \mu \mathrm{l}$ of $0.5 \mathrm{mg} / \mathrm{ml} \mathrm{CMC} \mathrm{or} 0.1 \%(\mathrm{w} / \mathrm{v})$ colloidal chitin and $270 \mu \mathrm{l}$ of the water sample were mixed. The colloidal chitin was prepared as previously described (Wietz et al., 2015). The reaction was terminated by $\mathrm{NaOH}$ and the contents of the produced reducing sugar was determined using the 3-Methyl-2-benzothiazolinonohydrazone method (Sastry and Vijaya, 1987). The casein reaction system contained $50 \mu \mathrm{l} 2 \%(\mathrm{w} / \mathrm{v})$ casein and $450 \mu \mathrm{l}$ of the water sample; the hydrolysis rate was measured as previously reported (Chen et al., 2002). Finally, tyrosine contents were measured by absorbance at $660 \mathrm{~nm}$. The alginic acid reaction system contained $50 \mu \mathrm{l}$ of $4 \mathrm{mg} / \mathrm{ml}$ alginic acid and $450 \mu \mathrm{l}$ of the water sample. After the termination of the reaction, the absorbance of the reaction mixture was measured at $235 \mathrm{~nm}$. All HMW substrate reactions were incubated for $20 \mathrm{~h}$. This long-time incubation may cause the overestimate of the EEA in the unfiltered seawater as microbes may grow and secrete new enzymes. Autoclaved seawater was used as the sample control; from this, the abiotic rate of hydrolysis was determined and subtracted for each assay. Triplicate incubations were conducted with unfiltered and filtrate water for each station. A standard curve was produced to allow conversion of absorbance into product concentration using a known amount of the corresponding monomer of the substrate except for alginic acid. One unit (U) of alginate lyase activity was defined as the amount of enzyme needed to produce an Absorbance 235 increase of 0.001 per hour (Xu et al., 2017). The sum of the hydrolysis rates measured for each station was calculated. Besides, the overall contribution of dissolved EEA to total EEA for the tested substrates was analyzed.

\section{DNA Extraction, PCR Amplification, and Phylogenetic Analysis}

Total genomic DNA from each sample was extracted following the protocol of PowerWater ${ }^{\circledR}$ DNA Isolation Kit 
(QIAGEN, Germany). Amplification of bacterial 16S rRNA gene fragments was performed using barcoded sequencing primers 338F (5'-ACTCCTACGGGAGGCAGCA-3') and 806R ( $5^{\prime}$-GGACTACHVGGGTWTCTAAT- $\left.3^{\prime}\right)$. Sequencing was conducted using an Illumina MiSeq platform (Majorbio BioPharm Technology Co., Ltd., China). Raw reads were trimmed, merged and filtered using Usearch (Edgar, 2018). Obtained reads were clustered into OTUs at a 97\% identity, and finally an OTUs table was generated. Taxonomy was assigned against RDP Naive Bayesian rRNA Classifier at an $80 \%$ confidence threshold based on representative OTU sequences (Liu and Wong, 2013). The phylogeny was estimated using the neighbor-joining algorithm based on the V3-V4 region of bacterial 16S rRNA gene sequences in MEGA 7 (Stecher et al., 2016). The phylogenetic tree was constituted of 31 OTU sequences and 16 referenced sequences from the NCBI database. Bacterial clades were defined by the marker sequences from published phylogenies.

\section{Statistical Analysis}

The cluster diagram, non-metric multidimensional scaling (NMDS) and one-way analysis of similarity (ANOSIM) were conducted using Primer 6 (Plymouth Marine Laboratory, United Kingdom). Cluster diagrams of total EEA and dissolved EEA were also performed on data from two different temperature regimes. Bacterial community compositions and comparisons to relative abundances in different stations were performed by $\mathrm{R}$ software. Redundancy analyses (RDAs), with Monte Carlo permutation tests, were implemented to estimate the relationships between total or dissolved EEAs and environmental factors by CANOCO (Version 5, Microcomputer Power). Screened environmental factors without multicollinearity effects (variance inflation factor $<20$ ) were used to explain enzyme activity variability. A Pearson's correlation index was calculated to determine correlations between DOC content and latitude. Wilcoxon's rank test was performed using $\mathrm{R}$ software to compare different enzyme activities from the inshore and offshore regions. The Illumina sequences were deposited in the National Center for Biotechnology Information (NCBI) Short Read Archive database under accession number PRJNA517539.

\section{RESULTS}

\section{Physicochemical Characterization}

A total of 11 water samples from the southern Yellow Sea and East China Sea were obtained from a depth of approximately $2 \mathrm{~m}$ (Figure 1). Environmental variables of all the seawater samplings are listed in Supplementary Table S1. The temperature at the sampling stations ranged from 19.2 to $28.2^{\circ} \mathrm{C}$ with an average of $25.3^{\circ} \mathrm{C}$. Stations D4 and F1 had very low salinity $(<3.0 \%)$, which was almost certainly related to the input of freshwater from the Yangtze River. Inorganic nutrient concentrations $\left(\mathrm{PO}_{4}{ }^{3-}\right.$, $\mathrm{NO}_{2}{ }^{-}, \mathrm{NO}_{3}{ }^{-}$and $\mathrm{NH}_{4}{ }^{+}$) were significantly higher in the inshore regions than those in the offshore regions (Wilcoxon test, $p<0.05)$. The chl-a content ranged from 0.16 to $3.80 \mu \mathrm{g} \mathrm{L}^{-1}$ and was significantly higher in the inshore regions than that in the offshore regions (Wilcoxon test, $p<0.05$ ). It also showed strong positive correlations with $\mathrm{NO}_{2}{ }^{-}(r=0.80, p<0.01)$, $\mathrm{NO}_{3}{ }^{-}(r=0.79, p<0.01)$ and $\mathrm{NH}_{4}{ }^{+}(r=0.96, p<0.01)$. The NDMS and cluster dendrogram analyses showed that the inshore and the offshore stations clustered into two different groups based on differences in physicochemical factors (Supplementary Figure S1) (ANOSIM, $r=0.97, p=0.006$ ).

\section{Patterns of Extracellular Enzyme Activities}

For unfiltered and filtered concentrated water sample from each station, the enzyme assays were conducted both at 35 and $25^{\circ} \mathrm{C}$, respectively. In the $35^{\circ} \mathrm{C}$ assays, hydrolysis of all tested substrates was observed (Figure 2). For total EEAs, among small molecule sugars, the average hydrolysis rate of BG $(302 \pm 120 \mathrm{nmol}$ $\left.\mathrm{L}^{-1} \mathrm{~h}^{-1}\right)$ was significantly higher than that of NAG $(32 \pm 12$ nmol L $\left.{ }^{-1} \mathrm{~h}^{-1}\right)(p<0.01)$ and AG $\left(124 \pm 48 \mathrm{nmol} \mathrm{L}{ }^{-1} \mathrm{~h}^{-1}\right)$. For the polysaccharides, the average hydrolysis rate of CMC was $49 \pm 14 \mathrm{nmol} \mathrm{L}^{-1} \mathrm{~h}^{-1}$, which was higher than that of chitin $\left(16 \pm 6 \mathrm{nmol} \mathrm{L}^{-1} \mathrm{~h}^{-1}\right)$. The average activity of alginate lyase was $40 \pm 25 \times 10^{-3} \mathrm{U} / \mathrm{L}$. Compared with the hydrolysis rates of polysaccharides CMC and chitin, the hydrolysis rate of casein was much higher $\left(254 \pm 25 \mathrm{nmol} \mathrm{L}^{-1} \mathrm{~h}^{-1}\right)(p<0.01)$. The hydrolysis rate of $\mathrm{C} 12$ ranged from $23 \mathrm{nmol} \mathrm{L}{ }^{-1} \mathrm{~h}^{-1}$ to $214 \mathrm{nmol} \mathrm{L}^{-1} \mathrm{~h}^{-1}$. PDSH was hydrolyzed with the highest rate $\left(2895 \mathrm{nmol} \mathrm{L}^{-1} \mathrm{~h}^{-1}\right)$ among all tested substrates. Dissolved EEAs were lower than total EEAs for all tested substrates. Though AG was hydrolyzed rapidly by the total AGases, there was scarcely detectable hydrolysis in the filtered water, which suggests that most of the AGases in the coastal waters were cell-associated. In contrast, the hydrolysis of casein, CMC, chitin and alginic acid was predominantly driven by dissolved extracellular enzymes.

In the $25^{\circ} \mathrm{C}$ assays, the hydrolysis rates of eight substrates were measured due to scarcely detectable hydrolysis of AG (Supplementary Figure S2). Hydrolysis of all tested substrates at $25^{\circ} \mathrm{C}$ also showed an obvious rate variation along stations. Hydrolysis rates of eight substrates in total and dissolved waters ranged from nearly $790 \mathrm{nmol} \mathrm{L}^{-1} \mathrm{~h}^{-1}$ (for PDSH at station F1) to undetectable (for AG at station B5 and CMC and chitin at station T4). The $\mathrm{Q}_{10}$ value (represents the factor by which the hydrolysis rate increases from 25 to $35^{\circ} \mathrm{C}$ ) for each enzyme (except for AGase) from the different stations was ranged from 1.1 to 2.9 , showing that different enzyme classes have different $Q_{10}$ values and the stoichiometry of organic matter remineralization would change as the ocean warms. Therein, for total and dissolved EEAs, $\mathrm{Q}_{10}$ values of BGase were the highest (2.2 and 2.9) among the eight tested enzymes.

\section{Comparison of Summed Enzyme Activities}

The contribution of the dissolved EEA to the total EEA was analyzed (Figure 3). The contribution of the dissolved AGase activity to the total AGase activity was extremely low $(<2 \%)$. Small proportions of Pase, BGase and NAGase activity were also found in the filtered water, which suggests that these enzymes were mainly cell-associated. In contrast to carbohydrase degrading small molecule sugars, polysaccharase were mainly 

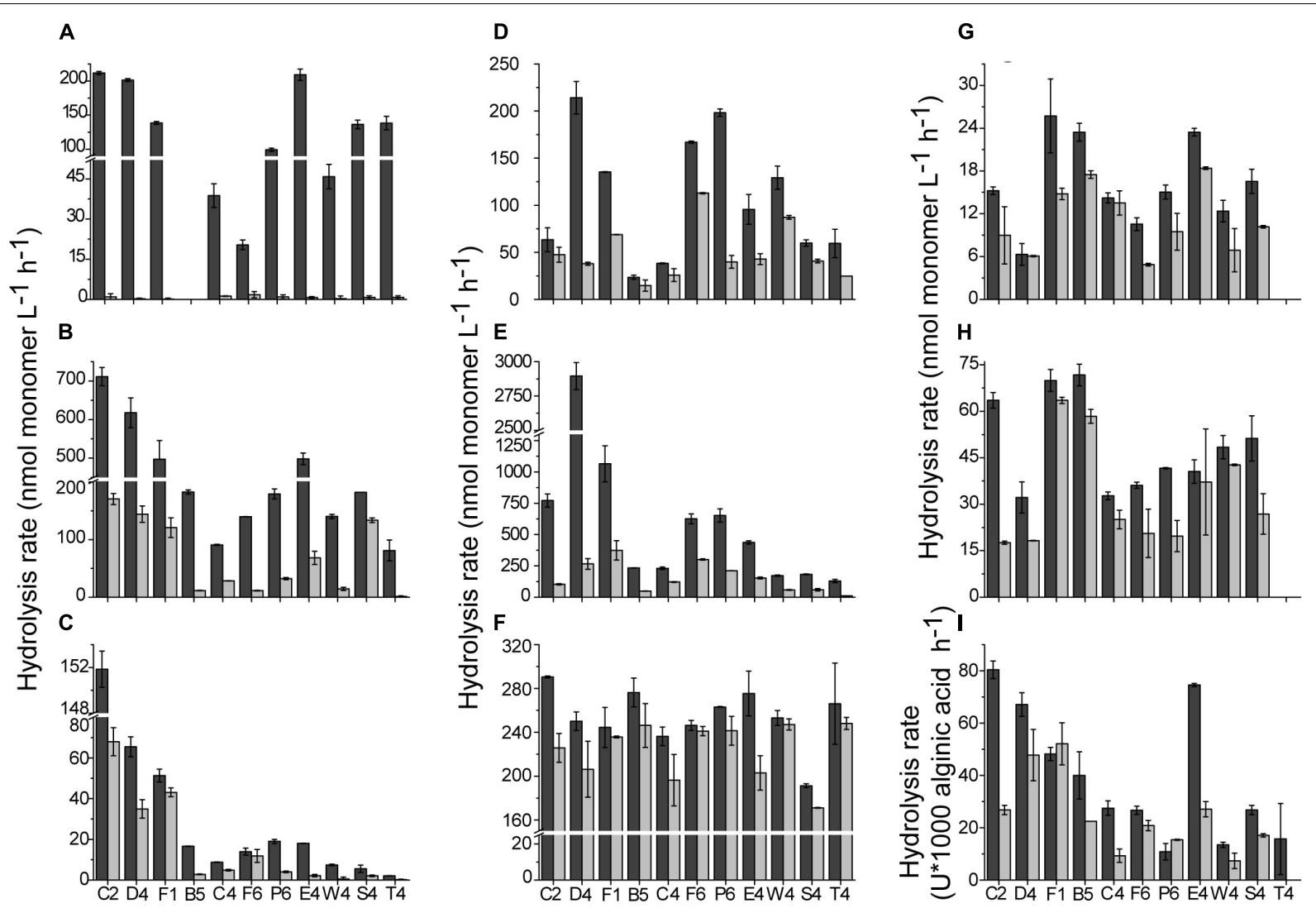

FIGURE 2 | The hydrolysis rates of tested substrates at $35^{\circ} \mathrm{C}$. (A) $\alpha$-D-glucopyranoside (AG). (B) $\beta$-D-glucopyranoside (BG). (C) N-acetyl- $\beta$-D-glucopyranoside (NAG). (D) Laurate (C12). (E) Phosphate disodium salt hexahydrate (PDSH). (F) Casein. (G) Chitin. (H) Carboxymethyl cellulose (CMC). (I) Alginic acid. Values are the mean hydrolysis rate in unfiltered water (dark gray), and 0.22- $\mu \mathrm{m}$ filtered water (light gray) at each station.

dissolved. During the incubations at $35^{\circ} \mathrm{C}$, the contributions of the dissolved to the total cellulase, chitinase and alginate lyase activity were $62 \pm 25 \%, 63 \pm 24 \%$ and $59 \pm 20 \%$, respectively (Figure 3A). During the incubations at $25^{\circ} \mathrm{C}$, for cellulose, the

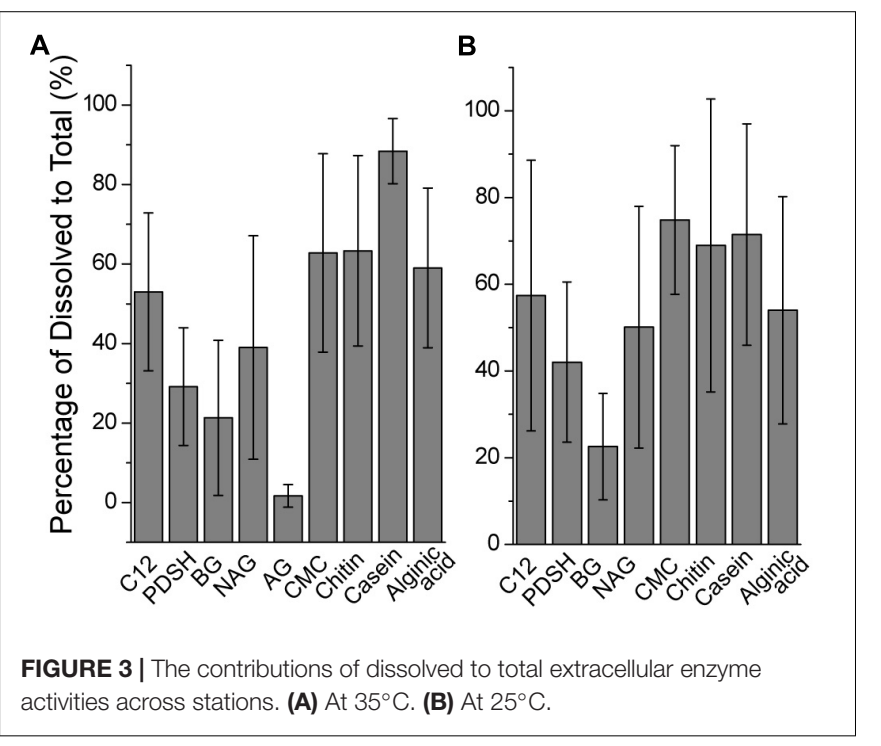

contribution of the dissolved to the total activity was the highest (75 $\pm 17 \%)$, followed by chitinase $(69 \pm 34 \%)$ and alginate lyase $(54 \pm 26 \%$ ) (Figure 3B). Protease activity in the filtered water made a large contribution $\left(88 \pm 8 \%\right.$ at $35^{\circ} \mathrm{C} ; 71 \pm 25 \%$ at $25^{\circ} \mathrm{C}$ ). The contribution of the dissolved fraction to the total activity of all tested enzyme activity varied significantly. This may be partly explained by microbial survival strategies, available substrate concentrations (Traving et al., 2015) and the method used to measure enzyme activity (Arnosti, 2010).

The hydrolysis rate of the different substrates (except for alginic acid) at each station was summed to present the potential hydrolysis at each station (Figure 4). Summed activities of total and dissolved extracellular enzymes varied across stations. For total EEAs, the highest summed enzyme activity was detected at station D4 $\left(4283 \mathrm{nmol} \mathrm{L}{ }^{-1} \mathrm{~h}^{-1}\right.$ at $35^{\circ} \mathrm{C} ; 1566 \mathrm{nmol} \mathrm{L}^{-1} \mathrm{~h}^{-1}$ at $25^{\circ} \mathrm{C}$ ). The total enzyme activity at stations $\mathrm{C} 2$ and $\mathrm{F} 1$ were also high. For dissolved EEAs, the highest summed enzyme activity was detected at station F1 $\left(920 \mathrm{nmol} \mathrm{L}^{-1} \mathrm{~h}^{-1}\right.$ at $35^{\circ} \mathrm{C}$; $915 \mathrm{nmol} \mathrm{L}^{-1} \mathrm{~h}^{-1}$ at $\left.25^{\circ} \mathrm{C}\right)$, followed by the station D4 (713 nmol $\mathrm{L}^{-1} \mathrm{~h}^{-1}$ at $35^{\circ} \mathrm{C} ; 700 \mathrm{nmol} \mathrm{L}{ }^{-1} \mathrm{~h}^{-1}$ at $25^{\circ} \mathrm{C}$ ). For each station, Pase, BGase and protease activity made a major contribution to the summed activity. Inshore waters, especially in the estuary, presented higher enzyme activity than the offshore waters. The cluster dendrograms of enzyme activity showed that the enzyme 


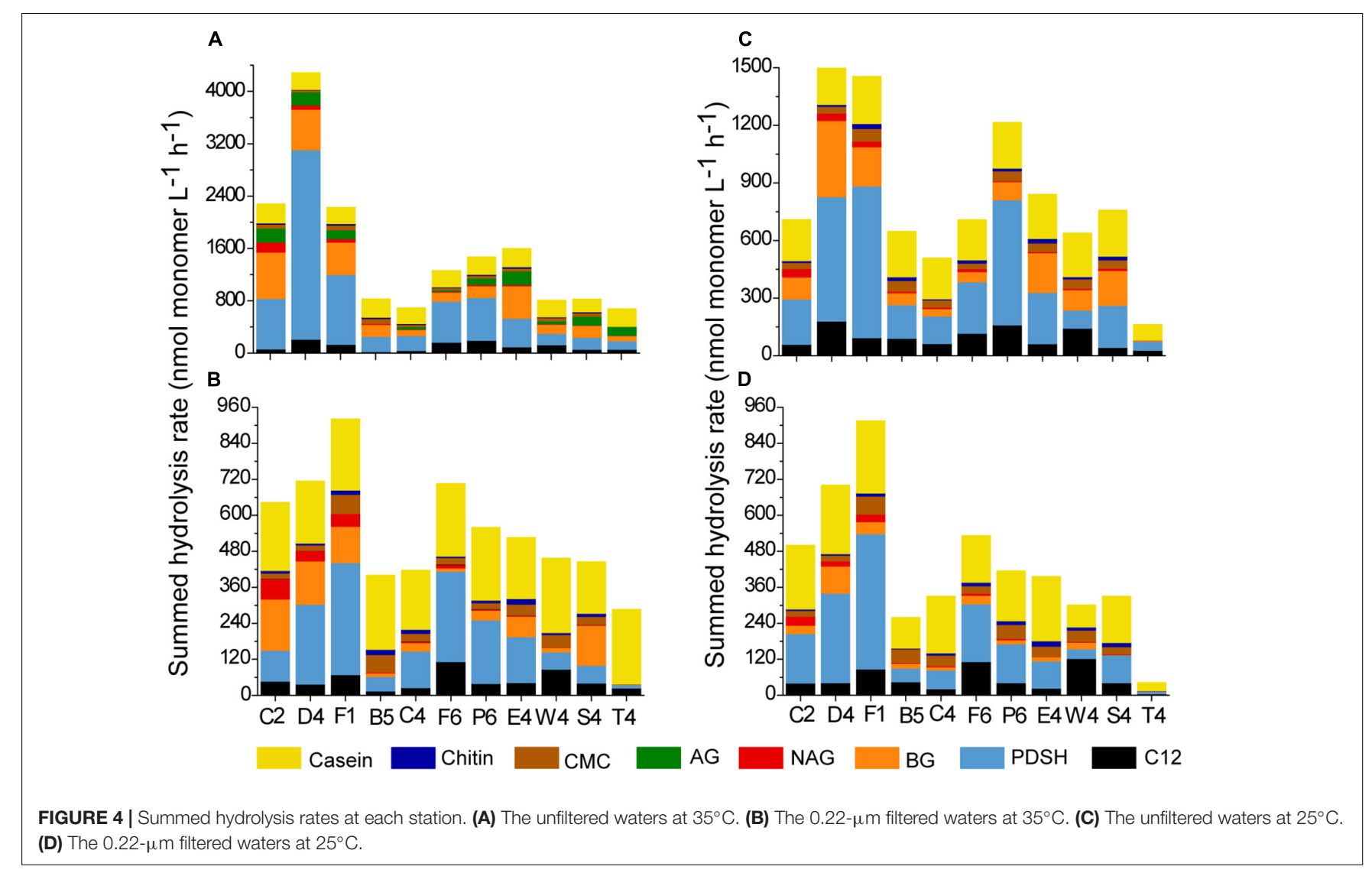

activity from inshore waters grouped together and were different from those of offshore waters (Supplementary Figure S3).

Based on the same chemical structure and the different degree of polymerization, the hydrolysis rates of the polymers (CMC and chitin) and corresponding oligomers (BG and NAG) were compared to analyze the effect of substrate size on hydrolysis rate (Figure 5). In the unfiltered water, the hydrolysis rates of BG from all stations were significantly higher than those of CMC $(p<0.01)$. NAG in each inshore station was hydrolyzed at a higher rate than chitin, but in each offshore station, it was hydrolyzed at a lower rate. This suggests that some polymers could be hydrolyzed at lower rates in inshore regions but at higher rates in offshore regions compared with corresponding oligomers. This situation also occurred in the dissolved NAGase and chitinase (Supplementary Table S2). For dissolved BGase and cellulase, the BGase activity at most stations at $35^{\circ} \mathrm{C}$ was higher than the cellulase activity.

\section{Environmental Factors Associated With Enzyme Activity}

The RDAs were performed to investigate the environmental factors responsible for shaping enzyme activity (Figure 6). The environmental factors without multicollinearity effects provided high explanatory powers $(>70 \%)$ for the total and dissolved enzyme activities. For total EEAs at $35^{\circ} \mathrm{C}$, Monte Carlo permutation tests showed that latitude was the most significant environmental factor, followed by DOC, chl-a and
$\mathrm{PO}_{4}{ }^{3-}$ (Figure 6A). The hydrolysis rates of CMC and chitin showed close, positive relationships with DOC and latitude, respectively. The hydrolysis rates of NAG, BG and $\mathrm{PDSH}$ were found to be positively correlated with chl-a and $\mathrm{PO}_{4}{ }^{3-}$. For dissolved EEAs at $35^{\circ} \mathrm{C}$, DOC was the only significant factor accounting for the variability $(p<0.05)$ (Figure 6B). The hydrolysis rate of NAG was found to be closely related to chl-a and $\mathrm{PO}_{4}{ }^{3-}$. The hydrolysis rates of $\mathrm{BG}$ and $\mathrm{PDSH}$ were positively correlated with latitude and DOC, respectively. For EEAs at $25^{\circ} \mathrm{C}$, latitude had the highest RDA explanatory power (23.8 and 33.1\%) on the total and dissolved enzyme activity, followed by $\mathrm{PO}_{4}{ }^{3-}$, chl-a, and salinity (Figures 6C,D). The hydrolysis rates of BG, NAG and PDSH were also highly positively related to latitude, DOC and chl-a. These RDA results showed that latitude and DOC were associated with the distribution of EEA on a large scale. Chla, salinity and $\mathrm{PO}_{4}{ }^{3-}$ also were correlated to NAGase, BGase and Pase activity at inshore stations.

\section{DISCUSSION}

\section{Specific Enzyme Activity Involved in Carbon, Nitrogen and Phosphorus Cycling}

Lipases, alginate lyases and carbohydrases play important roles in the marine carbon cycle (Imai et al., 1993; Xu et al., 2017). In the pelagic ocean, lipases from marine gliding bacteria were detected 


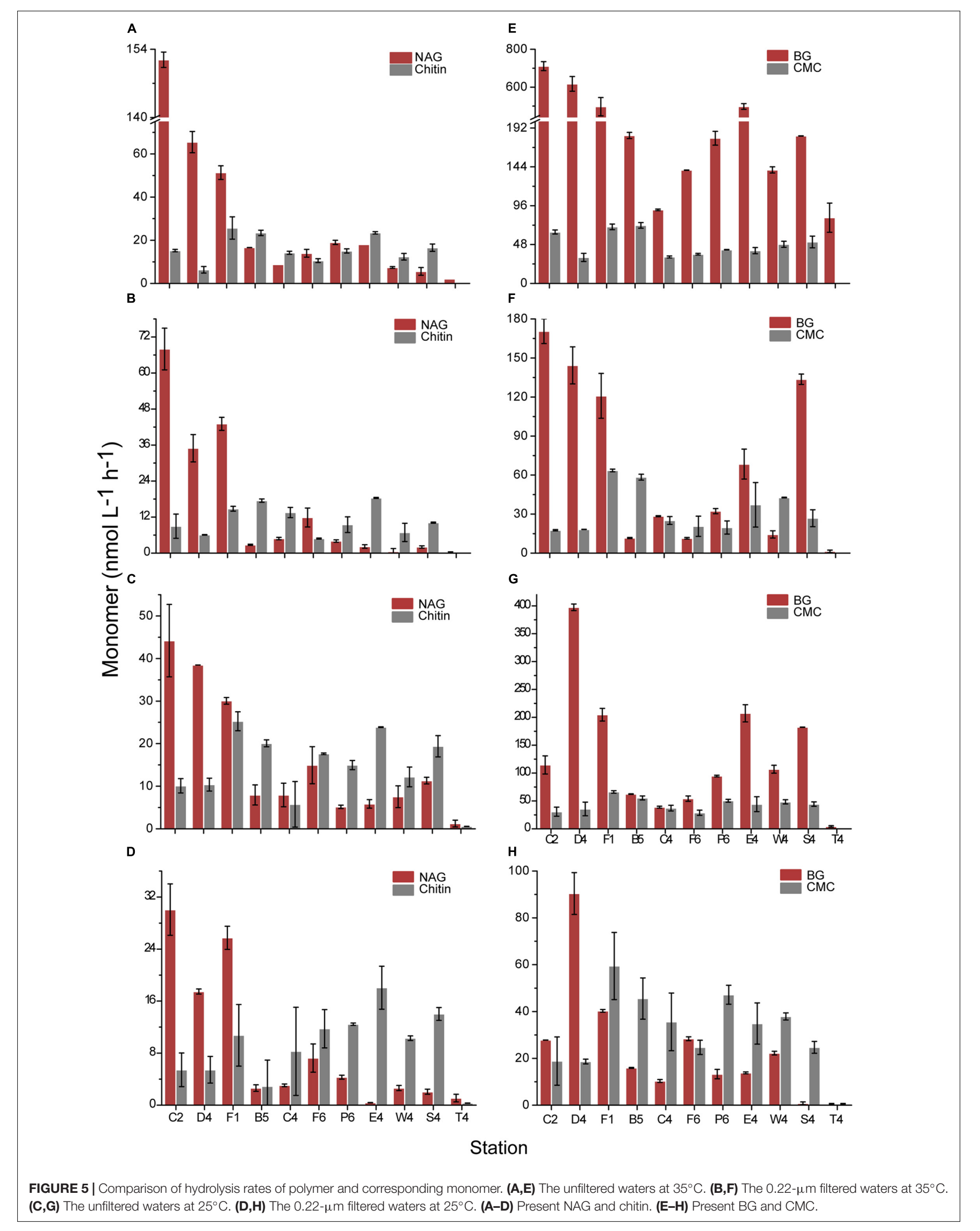



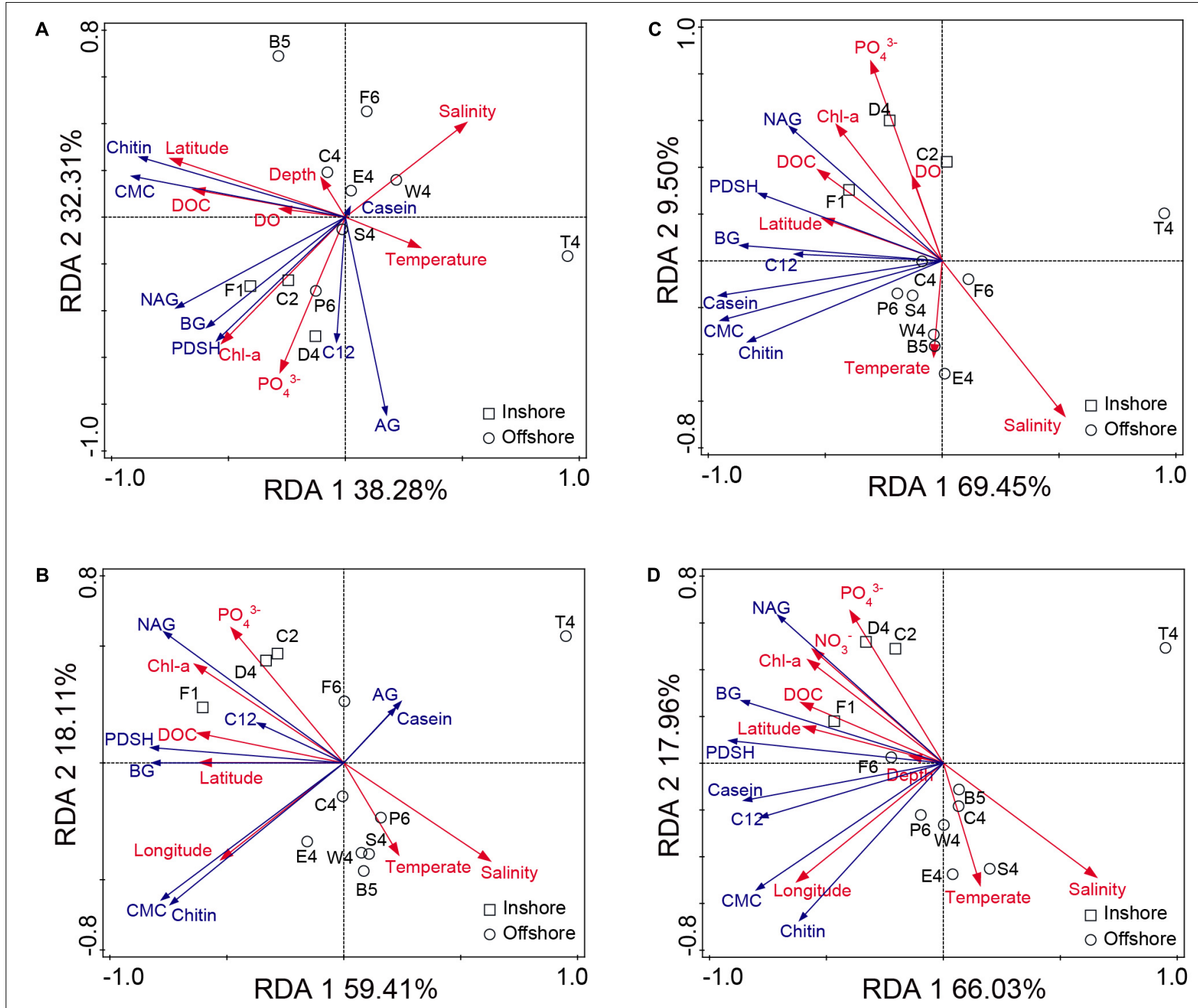

FIGURE 6 | Redundancy analyses (RDA) between environmental parameters and EEAs. (A) The total enzyme activities at $35^{\circ} \mathrm{C}$. (B) The dissolved enzyme activities at $35^{\circ} \mathrm{C}$. (C) The total enzyme activities at $25^{\circ} \mathrm{C}$. (D) The dissolved enzyme activities at $25^{\circ} \mathrm{C}$.

and could decompose cell membranes of dead organisms such as protozoa and phytoplankton (Imai et al., 1993). In this study, in situ lipase activity $\left(\sim 200 \mathrm{nmol} \mathrm{L} \mathrm{L}^{-1} \mathrm{~h}^{-1}\right)$ was also detected. Alginate lyases, which are synthesized by microbes, brown seaweeds and marine molluscs (Yin, 2015; Xu et al., 2017), showed different activities in the tested stations. Although AGase and BGase are both able to hydrolyze oligosaccharides and release monosaccharides (Dick, 2011), the hydrolysis rate of BG was much higher than that of AG in the unfiltered or $0.22-\mu \mathrm{m}$ filtered water (Figures 2A,B). This may be due to BGase's central position in global carbon cycling as BGase catalyzes the final step in the breakdown of cellulose, which mediates the subsequent supply of monomer glucose to microorganisms (Luo et al., 2017).

As an indicator of nitrogen acquisition, NAGase has an important function in nitrogen cycling (Shi et al., 2012; Sistla and Schimel, 2013). The general substrates for NAGase are chitin and peptidoglycan, which both are structural materials in marine invertebrates, fungi, algae and bacteria (Riemann and Azam, 2002). In the inshore stations with high availability of nitrogen, high NAGase activity was detected, which implies a rising microbial demand for nitrogen (Figure 2C and Supplementary Figure S2C) (Min et al., 2011). Protease activity, which acts to degrade multiple proteinaceous substrates that can be utilized by microorganisms as both carbon and nitrogen sources, was detected in all samples.

In many cases, Pase activity generally acts as a good indicator of the phosphorus supply for bacteria and phytoplankton (Hoppe, 2003; Luo et al., 2017). However, in some cases, Pase activities are decoupled from phosphate concentrations (Thomson et al., 2019). In comparison with the other enzymes tested in this study, Pase showed the highest activity at both 35 and $25^{\circ} \mathrm{C}$ (Figure 2E and Supplementary Figure S2E), the 
distributions of which were positively correlated with these of $\mathrm{PO}_{4}{ }^{3-}$ (Pearson's correlation test, for total EEA at $35^{\circ} \mathrm{C}$, $r=0.86, p<0.01$; for dissolved EEA at $35^{\circ} \mathrm{C}, r=0.41$, $p<0.05$; for total EEA at $25^{\circ} \mathrm{C}, r=0.54, p<0.05$; for dissolved $\mathrm{EEA}$ at $25^{\circ} \mathrm{C}, r=0.65, p<0.05$ ) (Figure 6). Particularly, at stations D4 and F1 near the Yangtze River estuary, PDSH was hydrolyzed very rapidly. Interestingly, as the end-product, high concentration inorganic phosphorus apparently did not inhibit Pase activities. This may be due to the presence of long lived Pase and the potential for spatial and temporal decoupling between the inorganic phosphorus concentrations and the Pase activity (Thomson et al., 2019). It has been reported that the proportion of the dissolved fraction to the total Pase activity can be as high as 70\% (Hoppe, 2003; Thomson et al., 2019). In this study, the dissolved fraction also made a relatively large contribution to the total Pase activity (up to $40 \%$ ). These dissolved Pase may originate from marine protozoa, bacterial stress and mortality (Baltar et al., 2019). Due to long lifetime, they can persistently function in the ocean, which serve as an example of the potential critical role that dissolved enzymes play in the ecology and biogeochemistry of the ocean (Baltar, 2018; Thomson et al., 2019).

In this study, the hydrolysis rates of different substrates were relatively higher but in the same order of magnitude as compared with previous studies. For example, it was reported that the Pase activities could reach $200 \mathrm{nmol} \mathrm{L}^{-1} \mathrm{~h}^{-1}$ in the coastal southern California (Allison et al., 2012), which was lower than Pase activities measured (300-700 nmol L $\mathrm{L}^{-1} \mathrm{~h}^{-1}$ ) in this study. Enzymatic activities in the open ocean were orders of magnitude lower than that in the marginal seas (Baltar et al., 2010, 2013). This may be due to the input of terrestrial freshwater, which might have provided both high nutrients and microbial cells that could stimulate enzyme production (Arnosti, 2004; Baltar et al., 2010). Besides, human activities, high incubation temperature and different methods of measurement are likely to be responsible for the high EEA in this study. The detected activity of a diverse range of extracellular enzymes indicates that the tested organic substrates, such as chitin, lipid and protein, can be hydrolyzed and utilized by marine microorganisms. Elevated temperature increases the enzymatic activity, implying that warming of seawater could accelerate the organic matter cycling rates in the marine ecosystem.

\section{Differences in Enzyme Activity Toward Polymer and Corresponding Oligomer}

Compared to the polymers CMC and chitin, the oligomers BG and NAG from inshore waters, especially in the estuary, were hydrolyzed at higher rates than those from offshore waters, which indicates that the hydrolysis rates of the smaller substrates were susceptible to terrestrial influences. Frequently, hydrolysis rates of polymers are lower than those of corresponding oligomers; this was found for CMC and BG at most stations. However, there were inconsistencies in that HMW substrates were hydrolyzed at higher rates (Pantoja and Lee, 1999) or were hydrolyzed at the same rates as their smaller components (Arnosti and Repeta, 1994; Arnosti et al., 1994). In offshore stations, for example, chitin was hydrolyzed faster than NAG (Figures 5A-D).
Molecule size may not necessarily limit the turnover of organic matter in marine systems (Arnosti, 2014). The nature of the substrate structure is also important to determine the hydrolysis rate (Pantoja and Lee, 1999). The hydrolysis rates of these substrates were also related to action modes of enzymes. In aquatic ecosystems, polymers are efficiently cleaved into oligomers by endohydrolases or monomers by exohydrolases (Obayashi and Suzuki, 2005; Weiner et al., 2008). However, consumption of these polymers may also occur through the production of oligomers that are of a suitable size for bacterial uptake, not just monomers (Arnosti et al., 2014). Some microbes even prefer to take up oligomers relative to monomers (Cotta and Zeltwanger, 1995).

\section{Effects of Environmental Factors on Enzyme Activity}

Different kinds of enzymes are known to responded flexibly to changes in environmental conditions and this causes spatial and temporal variation in their distribution in the ocean (Arnosti, 2014). Near the Yangtze River estuary, the stations D4 and F1 had low salinities $(<3.0 \%)$, due to input of substantial freshwater from Yangtze River. The freshwater input might have provided a terrestrial source of nutrients or microbial cells that could stimulate enzyme production (Allison et al., 2012; Millar et al., 2015), as observed at stations D4 and F1, which had high inorganic nutrient concentrations $\left(\mathrm{PO}_{4}{ }^{3-}, \mathrm{NO}_{2}{ }^{-}\right.$, $\mathrm{NO}_{3}{ }^{-}$, and $\mathrm{NH}_{4}{ }^{+}$). Phytoplankton dynamics, especially blooms accompanied by changes in nutrient conditions and $\mathrm{CO}_{2}$, can affect marine enzyme activity distribution (Allison et al., 2012; Arnosti, 2014). In line with this, elevated enzyme activity was found in the inshore stations with high chl-a contents (Figure 5).

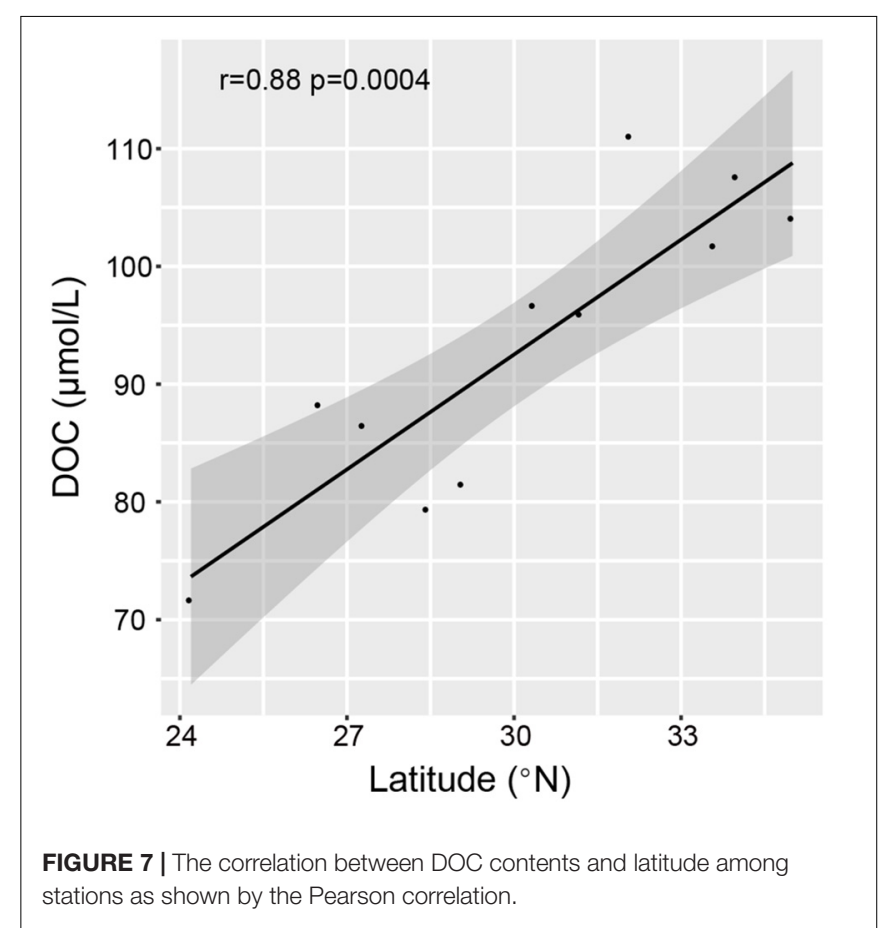


Based on the RDA analyses, latitude and DOC were closely associated with the total and dissolved enzyme activity (Figure 6). Summed hydrolysis rates for all tested substrates increased first and then decreased with increasing latitude (Supplementary Figure S4). However, latitude alone is a geographical factor and cannot have a direct relationship with the distribution of enzyme activity. It was found that DOC had a high collinearity with latitude (Figure 6), and DOC was significantly positively related to latitude through the Pearson's correlation test $(r=0.88$, $p<0.01$ ) (Figure 7). Therefore, it is speculated that DOC was an important factor associated with the geographic distribution of EEA. As one of the largest active organic carbon reservoirs on earth, marine DOC is the basic component of the matter cycle and shapes the variation of microbial EEA in the ocean (Arnosti, 2010; Li et al., 2018).

In this study, for each tested substrate, the hydrolysis rate at $35^{\circ} \mathrm{C}$ was higher than that at $25^{\circ} \mathrm{C}$. As reported, without the effect of other environment factors, increases in temperature alone should, within limits, result in increased enzyme activity (Price and Sowers, 2004). Except for the direct effect of temperature on EEA, however, warming is also expected to affect oceanic enzyme activity on a large scale by changing vertical mixing and nutrient distribution patterns in these water bodies (Pomeroy and Wiebe, 2001). This might cause a shift in the spectrum of EEA acting at different ocean levels (Cunha et al., 2010). Interestingly, different $\mathrm{Q}_{10}$ values were found for different enzyme classes in this study, which implied that stoichiometry of organic matter remineralization would change as the ocean warms.

\section{Connecting Bacterial Communities and Enzyme Activity}

Microbial community composition can shape enzyme patterns (Rietl et al., 2016). The bacterial community structure of seven stations (Figure 8) was investigated herein. Many marine bacterial phyla such as Bacteroidetes, Planctomycetes, Chloroflexi and Proteobacteria, which have the ability to produce a variety of extracellular enzymes, particularly polysaccharases (Teske et al., 2011), were found and most of them were abundant in this study. In the 16S rRNA gene clone libraries, marine Roseobacter lineages (OTU_3) within the class Alphaproteobacteria dominated. They are common members of coastal bacterioplankton and are often observed as particle-colonizers (Teske et al., 2011). The next most abundant lineage was Pseudoalteromonas (OTU_8) within the class Gammaproteobacteria. This lineage can produce a broad range of hydrolases (e.g., alginate lyase, carrageenase and peptidase) in response to available phytoplankton detritus (Gihring et al., 2009; Qin et al., 2010; Xu et al., 2017). Other gammaproteobacterial genera (Alteromonas (OTU_5), Vibrio (OTU_149), Pseudomonas (OTU_91), Psychrobacter (OTU_614) and Shewanella (OTU_239)) that can secrete various enzymes
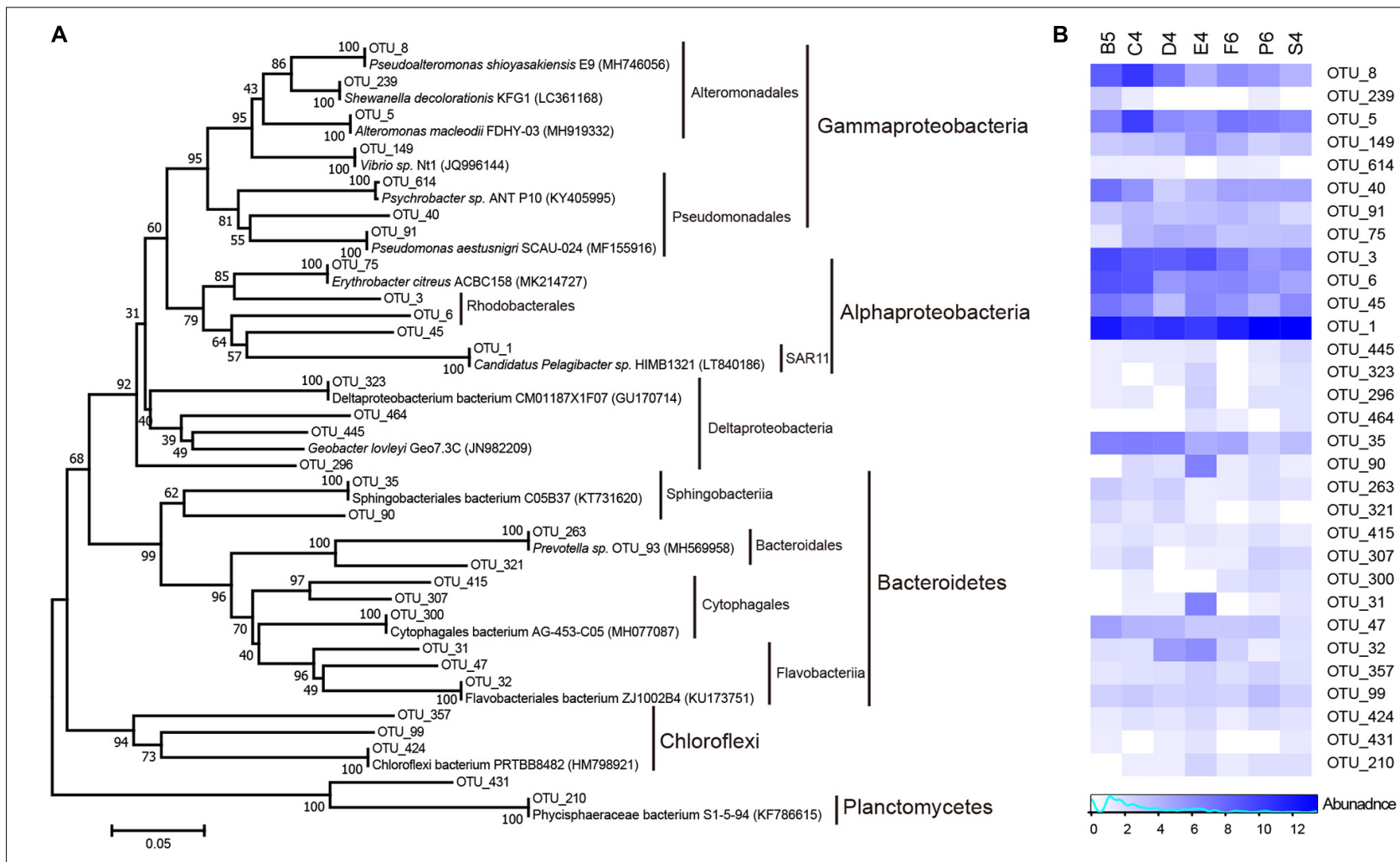

FIGURE 8 | Major producing enzyme clades in the north Chinese marginal seas. (A) Neighbor-joining phylogeny of bacterial phylotypes, based on partial 16S rRNA sequences. (B) Heatmap showing relative abundances for main microbes potentially producing various enzymes. Color bars represent the row-scaled value, in which a blue curve illustrates the distribution density percentage. 
to hydrolyze Tween 60 , pullulan and alginate were also found (Groudieva et al., 2004; Teske et al., 2011). Cultivating and molecular assays showed that some Chloroflexi populations can secrete xylanase, amylase, chitinase, esterase, galactosidase, and glucuronidase (Kragelund et al., 2007). Sphingobacteriia, Flavobacteriia, Cytophagia and Bacteroidia within the phylum Bacteroidetes were observed in this study. They are candidates for the hydrolysis of complex HMW carbohydrates and could assimilate phytoplankton phytodetritus quickly (Gihring et al., 2009).

In this study, a variety of high enzyme activities were potentially coupled with the bacterial clades Bacteroidetes, Roseobacter, Alteromonas, and Pseudoalteromonas, as also reported in a mesocosm study (Allison et al., 2012). However, these marine enzyme-producing bacteria were mostly selectively identified by whether they could be cultured or by whole-genome analyses, and these taxa were assumed to be responsible for the extracellular enzymes used in the in situ organic matter degradation. Next, together with in situ metatranscriptomic and metaproteomic analyses (Bergauer et al., 2018; Orsi et al., 2018), investigation on the direct links between different enzymes and microbial communities is needed.

\section{CONCLUSION}

This study investigated the distribution patterns of EEA in Chinese marginal seas. The enzyme activity showed geographical distribution pattern with latitude, which can mostly be explained by variations in DOC content. NAGase, BGase and Pase activities from inshore stations were mainly associated with chl-a, salinity and $\mathrm{PO}_{4}{ }^{3-}$ due to high freshwater input. High temperatures might also promote increased enzyme activity. Tested substrates were hydrolyzed at different rates and Pase, BGase and casease contributed the most to the summed activities. For each enzyme activity, the contribution of dissolved to total EEA was strongly variable between stations. Despite having the same chemical structures, differences in enzyme activity of tested polymers and their corresponding oligomers were intricate, which suggested that molecule size does not necessarily limit the turnover of marine organic matter. In addition, high enzyme activities were potentially coupled with the bacterial clades Bacteroidetes, Planctomycetes, Chloroflexi, Roseobacter, Alteromonas, and Pseudoalteromonas. In the future, more efforts

\section{REFERENCES}

Albertson, N. H., Nyström, T., and Kjelleberg, S. (1990). Exoprotease activity of two marine bacteria during starvation. Appl. Environ. Microbiol. 56, 218-223.

Alderkamp, A. C., Rijssel, M. V., and Bolhuis, H. (2007). Characterization of marine bacteria and the activity of their enzyme systems involved in degradation of the algal storage glucan laminarin. FEMS Microbiol. Ecol. 59, 108-117. doi: 10.1111/j.1574-6941.2006.00219.x

Allison, S. D., Chao, Y., Farrara, J. D., Hatosy, S., and Martiny, A. C. (2012). Finescale temporal variation in marine extracellular enzymes of coastal southern california. Front. Microbiol. 3:301. doi: 10.3389/fmicb.2012.00301

Arnosti, C. (2004). Speed bumps and barricades in the carbon cycle: substrate structural effects on carbon cycling. Mar. Chem 92, 263-273. doi: 10.1016/j. marchem.2004.06.030 will be needed to investigate the direct links between different enzyme activities and enzyme-producing communities.

\section{DATA AVAILABILITY}

The datasets generated for this study can be found in the National Center for Biotechnology Information (NCBI) Short Read Archive database: PRJNA517539.

\section{AUTHOR CONTRIBUTIONS}

YL, L-LS, Y-YS, and Q-QC performed the laboratory work. YL, L-LS, and C-YL collected the samples. YL wrote the manuscript. Q-LQ helped in the data analysis. Q-LQ, C-YL, X-LC, X-YS, MW, $\mathrm{AM}$, and D-LZ helped to revise the manuscript. Q-LQ and Y-ZZ designed the research.

\section{FUNDING}

The work was supported by the National Key R\&D Program of China (Grants 2018YFC1406504, 2016YFA0601303, and 2018YFC1406702), the National Natural Science Foundation of China (Grants 31670038, U1706207, 31570042, 91851205, 41706152, and 31870101), AoShan Talents Cultivation Program supported by Qingdao National Laboratory for Marine Science and Technology (2017ASTCP-OS14), Taishan Scholars Program of Shandong Province (2009TS079), and the Young Scholars Program of Shandong University (2016WLJH36).

\section{ACKNOWLEDGMENTS}

We thank Professor Gui-Peng Yang for providing environmental parameters data.

\section{SUPPLEMENTARY MATERIAL}

The Supplementary Material for this article can be found online at: https://www.frontiersin.org/articles/10.3389/fmicb. 2019.02137/full\#supplementary-material

Arnosti, C. (2010). Microbial extracellular enzymes and the marine carbon cycle. Ann. Rev. Mar Sci. 3, 401-425. doi: 10.1146/annurev-marine-120709142731

Arnosti, C. (2014). Patterns of microbially driven carbon cycling in the ocean: links between extracellular enzymes and microbial communities. Adv. Oceanogr. 2014, 1-12. doi: 10.1155/2014/706082

Arnosti, C., Bell, C., Moorhead, D. L., Sinsabaugh, R. L., Steen, A. D., Stromberger, M., et al. (2014). Extracellular enzymes in terrestrial, freshwater, and marine environments: perspectives on system variability and common research needs. Biogeochemistry 117, 5-21. doi: 10.1007/s10533-013-9906-5

Arnosti, C., Durkin, S., and Jeffrey, W. (2005). Patterns of extracellular enzyme activities among pelagic microbial communities: implications for cycling of dissolved organic carbon. Aquat. Microb. Ecol. 38, 135-145. doi: 10.3354/ ame038135 
Arnosti, C., and Repeta, D. J. (1994). Oligosaccharide degradation by anaerobic marine bacteria: characterization of an experimental system to study polymer degradation in sediments. Limnol. Oceanogr. 39, 1865-1877. doi: 10.4319/lo. 1994.39.8.1865

Arnosti, C., Repeta, D. J., and Blough, N. V. (1994). Rapid bacterial degradation of polysaccharides in anoxic marine systems. Geochim. Cosmochim. Acta 58, 2639-2652. doi: 10.1016/0016-7037(94)90134-1

Azam, F., Fenchel, T., Field, J. G., Gray, J. S., Meyer-Reil, L. A., and Thingstad, F. (1983). The ecological role of water-column microbes in the sea. Mar. Ecol. Prog. Ser. 10, 257-263. doi: 10.3354/meps010257

Azam, F., and Malfatti, F. (2007). Microbial structuring of marine ecosystems. Nat. Rev. Microbiol. 5, 782-791. doi: 10.1038/nrmicro1747

Baltar, F. (2018). Watch out for the "Living Dead": cell-free enzymes and their fate. Front. Microbiol. 8:2438. doi: 10.3389/fmicb.2017.02438

Baltar, F., Arístegui, J., Gasol, J. M., Herndl, G. J., Sintes, E., and van Aken, H. M. (2010). High dissolved extracellular enzymatic activity in the deep central Atlantic Ocean. Aquat. Microb. Ecol. 58, 287-302. doi: 10.3354/ame01377

Baltar, F., Arístegui, J., Gasol, J. M., Yokokawa, T., and Herndl, G. J. (2013). Bacterial versus archaeal origin of extracellular enzymatic activity in the Northeast Atlantic Deep Waters. Microb. Ecol. 65, 277-288. doi: 10.1007/ s00248-012-0126-7

Baltar, F., De Corte, D., and Yokokawa, T. (2019). Bacterial stress and mortality may be a source of cell-free enzymatic activity in the marine environment. Microbes Environ. 34, 83-88. doi: 10.1264/jsme2.ME18123

Baltar, F., Legrand, C., and Pinhassi, J. (2016). Cell-free extracellular enzymatic activity is linked to seasonal temperature changes: a case study in the Baltic Sea. Biogeosciences 13, 2815-2821. doi: 10.5194/bg-13-2815-016

Bergauer, K., Fernandez-Guerra, A., Garcia, J. A. L., Sprenger, R. R., Stepanauskas, R., Pachiadaki, M. G., et al. (2018). Organic matter processing by microbial communities throughout the Atlantic water column as revealed by metaproteomics. Proc. Natl. Acad. Sci. U.S.A. 115, E400-E408. doi: 10.1073/ pnas. 1708779115

Bochdansky, A. B., Puskaric, S., and Herndl, G. J. (1995). Influence of zooplankton grazing on free dissolved enzymes in the sea. Mar. Ecol. Prog. Ser. 121, 53-63. doi: $10.3354 /$ meps 121053

Celiker, H., and Gore, J. (2013). Cellular cooperation: insights from microbes. Trends Cell Biol. 23, 9-15. doi: 10.1016/j.tcb.2012.08.010

Chen, X.-L., Sun, C.-Y., Zhang, Y.-Z., and Gao, P.-J. (2002). Effects of different buffers on the thermostability and autolysis of a cold-adapted protease MCP-01. J. Protein Chem. 21, 523-527. doi: 10.1023/a:1022425621742

Chróst, R. J. (1991). "Microbial Ectoenzymes in Aquatic Environments," in Brock/Springer Series in Contemporary Bioscience, eds J. Overbeck, and R. J. Chróst, (New York, NY: Springer-Verlag), 47-78. doi: 10.1007/978-1-46123382-4_3

Cotta, M. A., and Zeltwanger, R. L. (1995). Degradation and utilization of xylan by the ruminal bacteria Butyrivibrio fibrisolvens and Selenomonas ruminantium. Appl. Environ. Microbiol. 61, 4396-4402. doi: 10.1049/ip-vis:20020372

Cunha, A., Almeida, A., Coelho, F., Gomes, N., Oliveira, V., and Santos, A. (2010). "Bacterial Extracellular Enzymatic Activity in Globally Changing Aquatic Ecosystems," in Current Research, Technology and Education Topics in Applied Microbiology and Microbial Biotechnology, Vol. 1, ed. A. Mendez-Vilas, (Badajoz: Formatex Microbiology Series), 124-135.

D’ambrosio, L., Ziervogel, K., Macgregor, B., Teske, A., and Arnosti, C. (2014). Composition and enzymatic function of particle-associated and free-living bacteria: a coastal/offshore comparison. ISME J. 8, 2167-2179. doi: 10.1038/ ismej.2014.67

Dick, R. P. (2011). Methods of Soil Enzymology. Madison: Soil Science Society of America, Inc.

Edgar, R. C. (2018). Accuracy of taxonomy prediction for 16S rRNA and fungal ITS sequences. PeerJ. 6:e4652. doi: 10.7717/peerj.4652

Fan, W., and Song, J. (2014). A numerical study of the seasonal variations of nutrients in the Changjiang River estuary and its adjacent sea area. Ecol. Modell. 291, 69-81. doi: 10.1016/j.ecolmodel.2014.07.026

Gihring, M., Humphrys, T., Mills, M., Huettel, H. M., and Kostka, E. J. (2009). Identification of phytodetritus-degrading microbial communities in sublittoral Gulf of Mexico sands. Limnol. Oceanogr 54, 1073-1083. doi: 10.4319/lo.2009. 54.4.1073

Grossart, H.-P., Tang, K. W., Kiørboe, T., and Ploug, H. (2007). Comparison of cell-specific activity between free-living and attached bacteria using isolates and natural assemblages. FEMS Microbiol. Lett. 266, 194-200. doi: 10.1111/j.15746968.2006.00520.x

Groudieva, T., Kambourova, M., Yusef, H., Royter, M., Grote, R., Trinks, H., et al. (2004). Diversity and cold-active hydrolytic enzymes of culturable bacteria associated with Arctic sea ice. Spitzbergen. Extremophiles 8, 475-488. doi: 10. 1007/s00792-004-0409-0

Hehemann, J.-H., Reintjes, G., Klassen, L., Smith, A. D., Ndeh, D., Arnosti, C., et al. (2019). Single cell fluorescence imaging of glycan uptake by intestinal bacteria. ISME J. 13, 1883-1889. doi: 10.1038/s41396-019-0406-Z

Holm-Hansen, O., Lorenzen, C. J., Holmes, R. W., and Strickland, J. D. H. (1965). Fluorometric determination of chlorophyll. J. Cons. perm. int. Explor. Mer. 30, 3-15. doi: 10.1093/icesjms/30.1.3

Hoppe, H.-G. (2003). Phosphatase activity in the sea. Hydrobiologia 493, 187-200. doi: 10.1023/a:1025453918247

Imai, I., Ishida, Y., and Hata, Y. (1993). Killing of marine phytoplankton by a gliding bacterium Cytophaga sp., isolated from the coastal sea of Japan. Mar. Biol. 116, 527-532. doi: 10.1007/bf00355470

Kim, C., Nishimura, Y., and Nagata, T. (2007). High potential activity of alkaline phosphatase in the benthic nepheloid layer of a large mesotrophic lake: implications for phosphorus regeneration in oxygenated hypolimnion. Aquat. Microb. Ecol. 49, 303-311. doi: 10.3354/ame01137

Kragelund, C., Thomsen, T. R., Kong, Y., Nielsen, P. H., Caterina, L., Rossetti, S., et al. (2007). Identity, abundance and ecophysiology of filamentous Chloroflexi species present in activated sludge treatment plants. FEMS Microbiol. Ecol. 59, 671-682. doi: 10.1111/j.1574-6941.2006.00251.x

Lee, Y., Choi, J. K., Youn, S., and Roh, S. (2014). Influence of the physical forcing of different water masses on the spatial and temporal distributions of picophytoplankton in the northern East China Sea. Cont. Shelf Res. 88, 216-227. doi: 10.1016/j.csr.2014.08.001

Li, Y., Sun, L.-L., Sun, M.-L., Su, H.-N., Zhang, X.-Y., Xie, B.-B., et al. (2018). Vertical and horizontal biogeographic patterns and major factors affecting bacterial communities in the open South China Sea. Sci. Rep. 8:8800. doi: 10.1038/s41598-018-27191-w

Liu, K.-L., and Wong, T.-T. (2013). Naïve bayesian classifiers with multinomial models for rRNA taxonomic assignment. Appl. Environ. Microbiol. 10, 1334 1339. doi: 10.1109/TCBB.2013.114

Luo, L., Meng, H., and Gu, J.-D. (2017). Microbial extracellular enzymes in biogeochemical cycling of ecosystems. J. Environ. Manag. 197, 539-549. doi: 10.1016/j.jenvman.2017.04.023

Millar, J. J., Payne, J. T., Ochs, C. A., and Jackson, C. R. (2015). Particle-associated and cell-free extracellular enzyme activity in relation to nutrient status of large tributaries of the lower mississippi river. Biogeochemistry 124, 255-271. doi: 10.1007/s10533-015-0096-1

Min, K., Kang, H., and Lee, D. (2011). Effects of ammonium and nitrate additions on carbon mineralization in wetland soils. Soil Biol. Biochem. 43, 2461-2469. doi: 10.1016/j.soilbio.2011.08.019

Obayashi, Y., and Suzuki, S. (2005). Proteolytic enzymes in coastal surface seawater: significant activity of endopeptidases and exopeptidases. Limnol. Oceanogr. 50, 722-726. doi: 10.2307/3597746

Orsi, W. D., Richards, T. A., and Francis, W. R. (2018). Predicted microbial secretomes and their target substrates in marine sediment. Nat. Microbiol. 3, 32-37. doi: 10.1038/s41564-017-0047-9

Pai, A., Tanouchi, Y., and You, L. (2012). Optimality and robustness in quorum sensing (QS)-mediated regulation of a costly public good enzyme. Proc. Natl. Acad. Sci. U.S.A. 109:19810. doi: 10.1073/pnas.12110 72109

Pantoja, S., and Lee, C. (1999). Peptide decomposition by extracellular hydrolysis in coastal seawater and salt marsh sediment. Mar. Chem. 63, 273-291. doi: 10.1016/S0304-4203(98)00067-X

Pomeroy, L. R., and Wiebe, W. J. (2001). Temperature and substrates as interactive limiting factors for marine heterotrophic bacteria. Aquat. Microb. Ecol. 23, 187-204. doi: 10.3354/ame023187

Price, P. B., and Sowers, T. (2004). Temperature dependence of metabolic rates for microbial growth, maintenance, and survival. Proc. Natl. Acad. Sci. U.S.A. 101, 4631-4636. doi: 10.1073/pnas.0400522101

Qin, Q.-L., Li, Y., Zhang, Y.-J., Zhou, Z.-M., Zhang, W.-X., Chen, X.-L., et al. (2010). Comparative genomics reveals a deep-sea sediment-adapted life style of Pseudoalteromonas sp. SM9913. ISME J. 5, 274-284. doi: 10.1038/ismej. 2010.103 
Reintjes, G., Arnosti, C., Fuchs, B., and Amann, R. (2019). Selfish, sharing and scavenging bacteria in the Atlantic Ocean: a biogeographical study of bacterial substrate utilisation. ISME J. 13, 1119-1132. doi: 10.1038/s41396-018-0326-3

Reintjes, G., Arnosti, C., Fuchs, B. M., and Amann, R. (2017). An alternative polysaccharide uptake mechanism of marine bacteria. ISME J. 11, 1640-1650. doi: 10.1038/ismej.2017.26

Riemann, L., and Azam, F. (2002). Widespread N-acetyl-D-glucosamine uptake among pelagic marine bacteria and its ecological implications. Appl. Environ. Microbiol. 68, 5554-5562. doi: 10.1128/aem.68.11.5554-5562.2002

Rietl, A. J., Overlander, M. E., Nyman, A. J., and Jackson, C. R. (2016). Microbial community composition and extracellular enzyme activities associated with Juncus roemerianus and Spartina alterniflora vegetated sediments in louisiana saltmarshes. Microb. Ecol. 71, 290-303. doi: 10.1007/s00248-015-0651-2

Sastry, C. S. P., and Vijaya, D. (1987). Spectrophotometric determination of some insecticides with 3-methyl-2-benzothiazolinone hydrazone hydrochloride. Talanta 34, 372-374. doi: 10.1016/0039-9140(87)80051-6

Shi, W., Bowman, D., and Rufty, T. (2012). "Microbial Control of Soil Carbon Accumulation in Turfgrass Systems," in Carbon Sequestration in Urban Ecosystems, eds R. Lal, and B. Augustin, (Dordrecht: Springer), 215-231. doi: 10.1007/978-94-007-2366-5_11

Sistla, S. A., and Schimel, J. P. (2013). Seasonal patterns of microbial extracellular enzyme activities in an arctic tundra soil: identifying direct and indirect effects of long-term summer warming. Soil Biol. Biochem. 66, 119-129. doi: 10.1016/j. soilbio.2013.07.003

Stecher, G., Kumar, S., and Tamura, K. (2016). MEGA7: molecular evolutionary genetics analysis version 7.0 for bigger datasets. Mol. Biol. Evol. 33, 1870-1874. doi: 10.1093/molbev/msw054

Su, Y.-S., and Weng, X.-C. (1994). "Water Masses in China Seas," in Oceanology of China Seas, eds Z. Di, L. Yuan-Bo, and Z. Cheng-Kui, (Dordrecht: Springer), 3-16. doi: 10.1007/978-94-011-0862-1_2

Teske, A., Durbin, A., Ziervogel, K., Cox, C., and Arnosti, C. (2011). Microbial community composition and function in permanently cold seawater and sediments from an arctic fjord of svalbard. Appl. Environ. Microbiol. 77, 20082018. doi: 10.1128/aem.01507-10

Thomson, B., Wenley, J., Currie, K., Hepburn, C., Herndl, G. J., and Baltar, F. (2019). Resolving the paradox: continuous cell-free alkaline phosphatase activity despite high phosphate concentrations. Mar. Chem. 214:103671. doi: 10.1016/j.marchem.2019.103671

Traving, S. J., Thygesen, U. H., Riemann, L., and Stedmon, C. A. (2015). A model of extracellular enzymes in free-living microbes: which strategy pays off? Appl. Environ. Microbiol. 81, 7385-7393. doi: 10.1128/aem. 02070-15
Vetter, Y. A., and Deming, J. W. (1999). Growth rates of marine bacterial isolates on particulate organic substrates solubilized by freely released extracellular enzymes. Microb. Ecol. 37, 86-94. doi: 10.1007/s0024899 00133

Wallenstein, M. D., and Weintraub, M. N. (2008). Emerging tools for measuring and modeling the in situ activity of soil extracellular enzymes. Soil Biol. Biochem. 40, 2098-2106. doi: 10.1016/j.soilbio.2008.01.024

Wei, Q.-S., Yu, Z.-G., Wang, B.-D., Fu, M.-Z., Xia, C.-S., Liu, L., et al. (2016). Coupling of the spatial-temporal distributions of nutrients and physical conditions in the southern Yellow Sea. J Mar. Syst. 156, 30-45. doi: 10.1016/ j.jmarsys.2015.12.001

Weiner, R. M., Taylor, L. E. II, Henrissat, B., Hauser, L., Land, M., Coutinho, P. M., et al. (2008). Complete genome sequence of the complex carbohydratedegrading marine bacterium, Saccharophagus degradans strain 2-40T. PLoS Genet. 4:e1000087. doi: 10.1371/journal.pgen.1000087

Weiss, M. S., Abele, U., Weckesser, J., Welte, W., Schiltz, E., and Schulz, G. E. (1991). Molecular architecture and electrostatic properties of a bacterial porin. Science 254:1627. doi: 10.1126/science.1721242

Wietz, M., Wemheuer, B., Simon, H., Giebel, H.-A., Seibt, M., Daniel, R., et al. (2015). Bacterial community dynamics during polysaccharide degradation at contrasting sites in the Southern and Atlantic Oceans. Environ. Microbiol. 17, 3822-3831. doi: 10.1111/1462-2920.12842

Xu, F., Dong, F., Wang, P., Cao, H.-Y., Li, C.-Y., Li, P.-Y., et al. (2017). Novel molecular insights into the catalytic mechanism of marine bacterial alginate lyase AlyGC from polysaccharide lyase family 6. J Biol. Chem. 292, 4457-4468. doi: 10.1074/jbc.M116.766030

Yin, H. (2015). Alginate lyase: review of major sources and classification, properties, structure-function analysis and applications AU Zhu. Benwei. Bioeng. 6, 125-131. doi: 10.1080/21655979.2015.10 30543

Conflict of Interest Statement: The authors declare that the research was conducted in the absence of any commercial or financial relationships that could be construed as a potential conflict of interest.

Copyright (c) 2019 Li, Sun, Sun, Cha, Li, Zhao, Song, Wang, McMinn, Chen, Zhang and Qin. This is an open-access article distributed under the terms of the Creative Commons Attribution License (CC BY). The use, distribution or reproduction in other forums is permitted, provided the original author(s) and the copyright owner(s) are credited and that the original publication in this journal is cited, in accordance with accepted academic practice. No use, distribution or reproduction is permitted which does not comply with these terms. 